\title{
Management Challenges in Special Nature Reserve "Gornje Podunavlje" and Preparations for its Proclamation of Biosphere Reserve
}

\author{
Vladimir Stojanović ${ }^{A *}$, Stevan Savić ${ }^{A}$ \\ Received: October 2013 | Revised: December 2013 | Accepted: December 2013
}

\begin{abstract}
Management of protected natural wetland habitats and flooded plains is a real challenge in nature protection. Such areas consist mainly of mosaic ecosystems, highly sensitive to all natural changes, especially to those of anthropogenic origin. Special nature reserve "Gornje Podunavlje" is one of the largest and most important wetland habitats in this part of Europe. The area is under protection, but for centuries it has been influenced by numerous economic activities. The institutions for nature protection and protected area management face numerous challenges regarding this issue. The paper focuses on the research of the landscape changes in "Gornje Podunavlje" and its surroundings. They have become a sensitive issue under the circumstances when "Gornje Podunavlje" and its broader areas have been nominated for biosphere reserve status.
\end{abstract}

Key words: protected area, landscape changes, "Gornje Podunavlje", management, biosphere reserve, Mura - Drava - Danube.

\section{Introduction}

Since its foundation, Special nature reserve "Gornje Podunavlje" has been managed by Public Enterprise Vojvodinašume in Petrovaradin. Active measures have been prescribed for this protected area. However, the area has been strongly influenced by agriculture, fishing, forestry and meliorations for centuries, leaving visible traces. Certain activities are currently creating a dilemma, especially the analysis of forestry development and its impact on ecosystems (Puzović, 2002). This activity is under jurisdiction of the management. On the other hand, numerous educational and tourism activities (Stojanović et al, 2013) contribute to popularity of nature protection in "Gornje Podunavlje". In accomplishing the task, the management is supported by professional and non-governmental organizations. Therefore, the activity span of the management starts at forestry development, which is mainly considered to have negative impact on habitats, and continues to pop- ularization of protection through educational activities and tourism development, which directly needs wild, pristine and preserved nature.

On the grounds of confronted opinions, it seems that all this area is urgently in need for the principle of sustainable development in exploitation of the resources and nature protection. This concept, based on ecologically, socio-culturally and economically balanced development (Baker, 2006; Elliott, 2013) may become useful in various protected areas (Stojanović, 2005). Sustainable tourism approach should be particularly directed to local population communities.

Trends and aims of sustainable utilisation of protected areas may also be found within the biosphere reserve concept. Biosphere reserves introduce a dynamic and acceptable concept of nature protection as a form of international status in nature protection that has the aim to integrate nature protection, research and exploitation in order to satisfy human

\footnotetext{
A Climatology and Hydrology Research Centre, Faculty of Science, University of Novi Sad, Trg Dositeja Obradovića 3, 21000 Novi Sad, Serbia

* Corresponding author: Vladimir Stojanović: vladimir_stojanovic@yahoo.com
} 


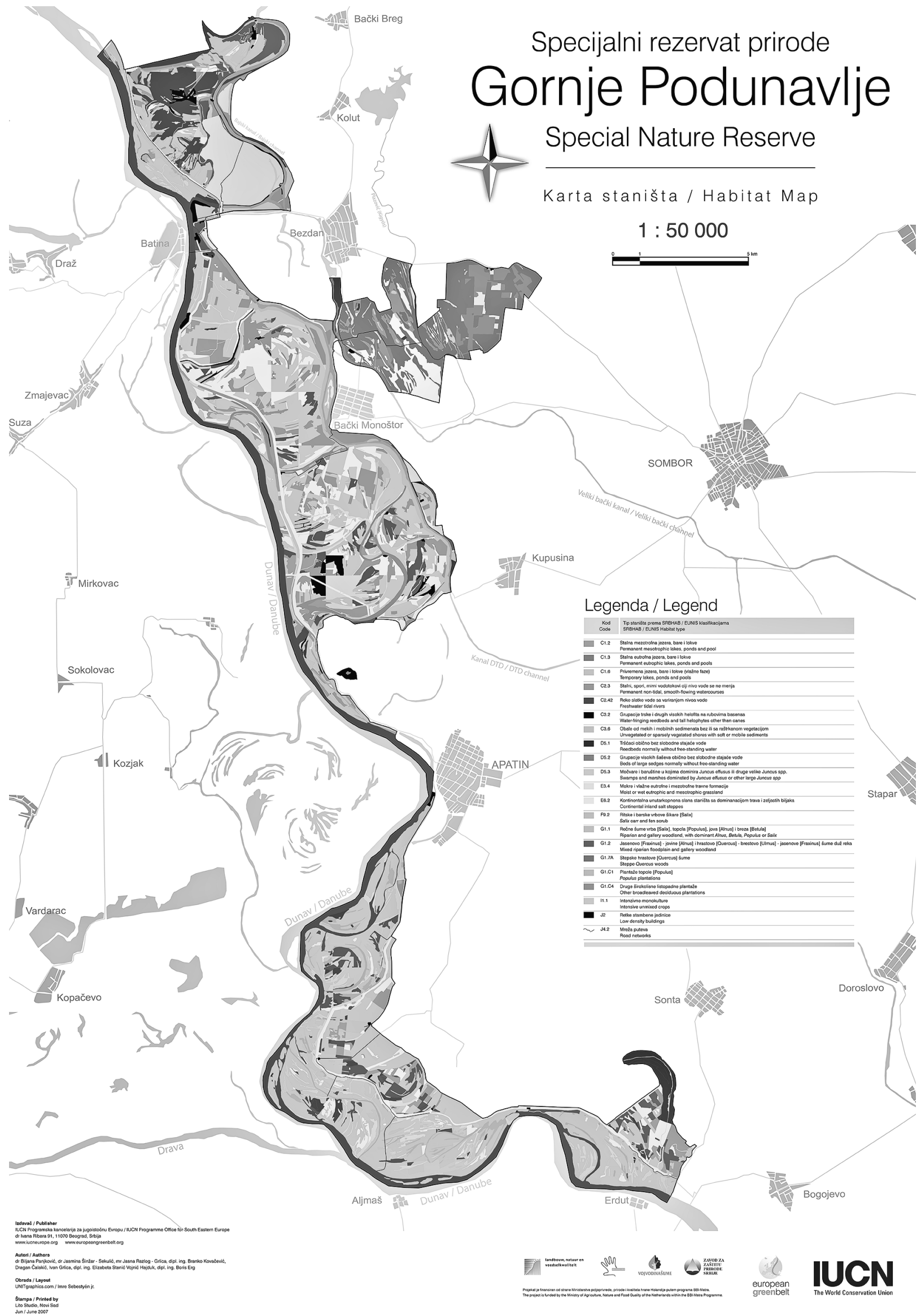

Figure 1. Habitat map in Special nature reserve "Gornje Podunavlje" Source: www.gornjepodunavlje.info 
needs (www.unesco.org). In essence it is based on sustainable development idea. "Gornje Podunavlje" with its broader area was nominated for the biosphere reserve Mura-Drava-Danube in 2013 (Panjković et al, 2013). This form of protection might become the turning point in current managerial concept and definitely a stronger impulse in sustainable resources exploitation in "Gornje Podunavlje".

\section{History and protection dynamics}

Special nature reserve "Gornje Podunavlje" is situated in the north-western part of Serbia (Vojvodina), near the Danube banks, including numerous habitats in Apatinski rit, Monoštorski rit and Karapandža (Figure 1). This area has always attracted people for its abundance in natural resources, and currently the reason is primarily nature protection. In broader surroundings of the reserve there are nine settlements with the population of 83,000.

The first activities in landscape protection and natural assets in this area commenced in the year 1955 when Institute for nature protection passed the resolution on protection of forests in Monoštor as habitats of White-tailed Eagle and Black Stork. Eight years later the municipality of Sombor reached the decision on protecting the mixture of trees: poplar, white poplar, willow, etc. in the area of Monoštorski rit (6oo ha) as a strict nature reserve. Moreover, following the proposal of the Provincial institute for nature protection, the municipality passed the resolution on protecting forests near Monoštor, as a strict nature reserve (74.93 ha). At the same time 6.06 ha of forests was put under protection as natural monument. The municipality of Apatin put under protection the area of Bestrement ( $9.63 \mathrm{ha}$ ) as a reserve for maintaining the fund of rare and endangered flora and fauna in 1987 . However, the most important year for creating the present protected area "Gornje Podunavlje" was 1982, when municipalities of Sombor and Apatin reached the decision, based on the proposal of Provincial institute for nature protection, to form Regional nature park "Gornje Podunavlje" (Kovačević et al, 200o).

The professionals from the Institute for nature protection of Serbia started revision and valorisation of "Gornje Podunavlje" in 1996. Field research was conducted in the period 1996-1998 to validate natural characteristics and decide upon the category of natural assets in concordance with the current law. In 2001, the whole process underwent the legal regulations and "Gornje Podunavlje" was pronounced a special nature reserve (Official gazette of the Republic of Serbia, No.45/2001).

"Gornje Podunavlje" is related to several international statuses in nature protection. Due to well- known ornithological values, this natural asset was added to the IBA area list under the name "Gornje Podunavlje" in 1989 (Greemet, Jones, 1989). It was added to the Ramsar list in 2007 (www.ramsar.org). "Gornje Podunavlje" became IPA area in 2007. In September 2013, "Gornje Podunavlje" together with its broader surroundings was nominated for Biospere reserve status (Mura - Drava - Danube). Simultaneously, this status would create the highest opportunity for improving protection activities through sustainable economic activities.

\section{Landscape changes due to exploitation of the resources}

"Gornje Podunavlje" with its surroundings has a complex landscape history. Inevitably, the activities of the people have changed significantly or even essentially the landscape. Each period in the development of human communities particularly influenced the evolution of natural features in the region.

Agriculture has been one of the most important human activities in this area for millennia. It is closely connected to first inhabitants of this part of the Pannonian plain. Archaeological site Donja Branjevina near the village Deronje contains the remains of Starčevo culture. The Early Neolithic Age brought significant changes to behaviour of the human communities. Survival strategy, based on hunting and gathering, was gradually replaced by food production through development of agriculture, primarily land cultivation. Mobility of hunting-gathering communities was replaced by trends of establishing permanent settlements. New technologies, necessary for everyday life were acquired (Medović, 2001). The present surroundings of the reserve are almost completely agricultural with dominating arable land. Parallel to agricultural development cattle breeding was developing especially in salt marshes (near Sombor, Sonta and Svilojevo) the areas suitable for this branch.

For centuries in the newer history there was the impression that Vojvodina was the abandoned and uncultivated land. It was only during the reign of the Habsburg Monarchy when huge regulation works were started aiming at populating and economic growth of the region. Colonisations were frequent in the mid $18^{\text {th }}$ century when, influenced by such activities and the need for numerous regulation works in the following period, the landscape started to change its original shape. Also, the population increase implied large-scale exploitation of various resources.

It was already in the $18^{\text {th }}$ century when fishing increased significantly. The short review of Sonta in 1720 asserted that the inhabitants of the village had large income, especially from fishing on the Danube, and fre- 
quently the turning point in fishing development was the Theresian colonisation, when Apatin was turned into a large admission centre for colonised Germans. From that time onwards there was the boom of crafts in the settlement. At the end of the $18^{\text {th }}$ century, there were $426 \mathrm{craftsmen}$ and 200 fishermen. They brought precious experience from their homeland (the upper Danube, the Rhine, and the Main), yet unknown to the inhabitants of this region. Among the most useful were the various uses of large fishing nets. When they formed their own guilds in 1830, the fishermen were in such large number that neither of the towns on the Danube from Bratislava to Orsova could be compared to Apatin by the number of professional fishermen (Bukvić, 1969). At that time the town had the leading role in freshwater fishing on the whole territory of Austria-Hungary. Fishing has remained one of the important economic activities up to the present.

Serous melioration works in Bačka started in the second half of the $18^{\text {th }}$ century when in large planned colonisation higher needs for arable land were created. Under the new circumstances it was necessary to undertake melioration works in order to drain the marshes and swamps and obtain more arable land (Petrović, 1978). The first most significant results in collecting excess ground waters and redirecting them to Crna bara - the flow $47 \mathrm{~km}$ long in south-west and south rim of Bačka loess plateau were visible in 1785 near Kula and Vrbas after the canal was digged between the two settlements. The designer of the canal was Jožef Kišnač who launched the initiative to extend the canal to Sivac. In that way the problem of water-drainage of large marshes and moors was solved. The canal Sivac-Vrbas-Crna bara, about $30 \mathrm{~km}$ long, had huge importance for its main purpose was gravity drainage of excess waters. Moreover, this canal was the base for the implementation of another great idea of Jožef Kišs, the building of the navigable canal beetween the Danube and the Tisa, i.e. the Great Bačka canal which was opened in 1802. Apart from its traffic role, this canal, was also a drainage system for excess water into the river Tisa (Milošev, 2002). The Great Bačka canal is situated in the Special nature reserve "Gornje Podunavlje".

The Danube flow was several times changed by cutting meanders to shorten the navigation route at the end of the $19^{\text {th }}$ century and beginning of $20^{\text {th }}$ century. On that occasion, regulation works on the digging of the Danube's new riverbed were conducted. Three water canals were dug:Blaževački, between $1,386^{\text {th }}$ and $1,383^{\text {th }}$ river kilometre, Sigajski between $1,416^{\text {th }}$ and $1,408^{\text {th }}$ river kilometre and Dravski between $1,386^{\text {th }}$ and $1,383^{\text {th }}$ river kilometre. Blaževački water canal cut off the meander around Blaževac, Sigajski water canal cut off the meanders around Veliki and Mali Kazuk,
Siga, Ampovo and Adica, whereas Dravski water canal cut off the meander surrounding Srebrnica (Bukurov, 1975). Besides these changes in "Gornje Podunavlje" there was a whole range of other smaller regulation works that had crucial impact on hydrography of the area and were conducted at the turn of the century. Among the most significant was the deepening of the meander bed Baračka in the northern part of the reserve. South from this bifurcation, South Bezdan canal was dug $(1,175 \mathrm{~m})$ and Ruvac Kopolja near the Great Bački canal had to be cut because it endangered the nearby dam (Borovszky, 1909). The number of regulation works, which are of vital importance for the inhabitants and settlements, is impossible to count in the whole area.

The dike building changed the physiognomy of the landscape in "Gornje Podunavlje". The dikes were built in previous centuries to protect settlements and cultivated land threatened by the Danube floods. Building and strengthening of the dikes was most prominent in the $2 \mathrm{O}^{\text {th }}$ century. One of the examples of total change in the scenery was the area of Siga - Kazuk inMonoštorski rit, which was joined to the protected part of alluvial plain after the building of the dike in 1966 (Hydrological study of Monoštorski rit Siga Kazuk, 1988). Comparative analysis of habitat conditions in Monoštorski and Apatinski rit, subject to the flooding Danube, offers the evidence on total change of landscape values under the influence of dike building. The area of Apatinski rit has mainly preserved its authentic features, but the area of Monoštorski rit has been degraded which is perceived in the changes of small vegetation, decreased forests growth, and decreased food potential for game. Finally, higher mobility of the people is provided which is an additional threat to the area.

\section{Management in Special nature reserve "Gornje Podunavlje"}

Special nature reserve "Gornje Podunavlje" has been managed by Public Company Vojvodinašume from Petrovaradin since its proclamation in July 2001. With the aim of its long-termed protection and preservation ten year management and annual management plans are designed with the following activities: planning documents and managing documents; custody and inspection; monitoring the condition; cooperation with users and stakeholders; protection and preservation of natural assets; measures for protection and exploitation of natural resources; development activities; scientific and research activities; cultural, educational, tourist - recreational activities; project activities; regulating and equipping the area; international cooperation; (Internal data and documents of 


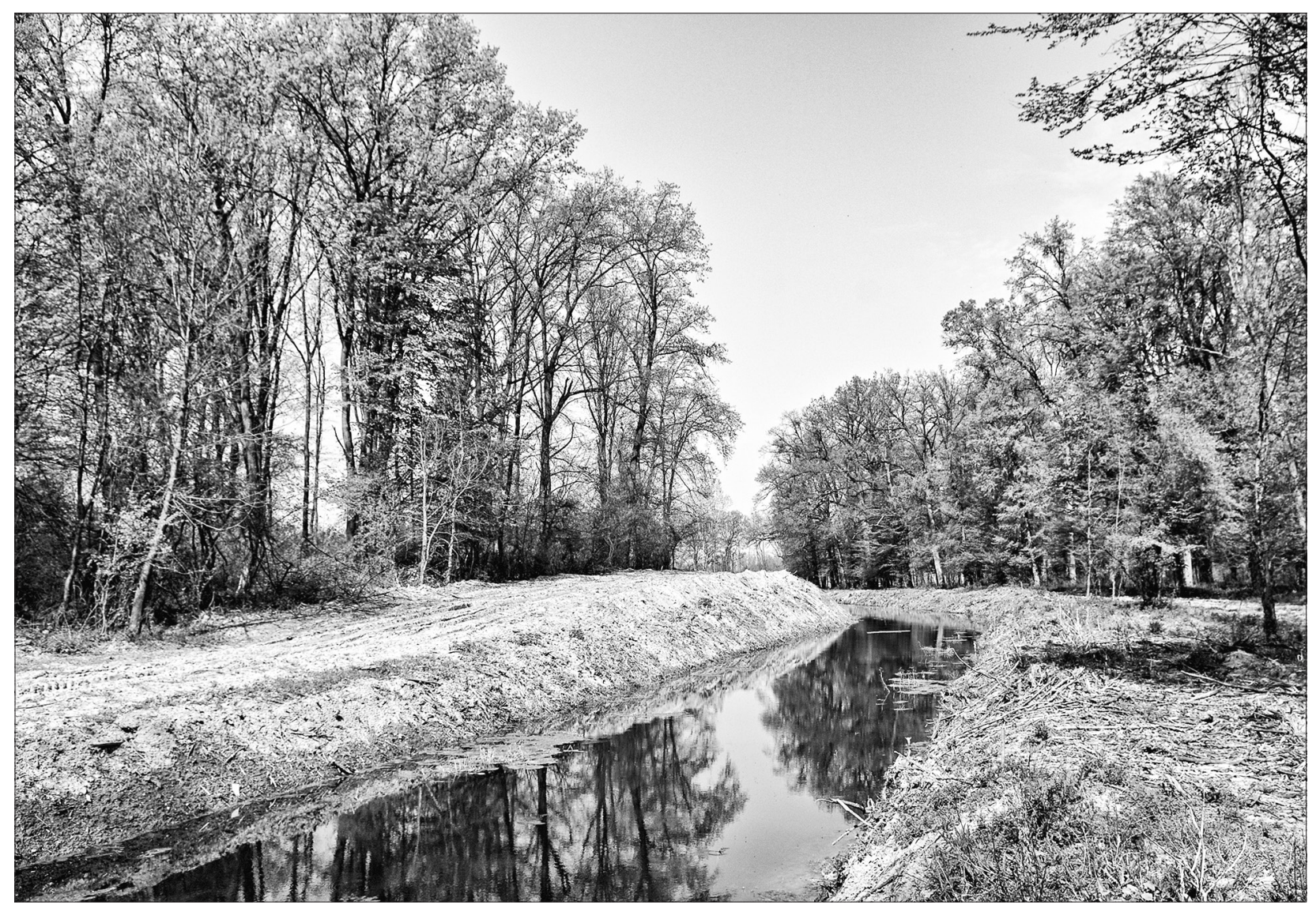

Figure 2. The water canal Sirota at the site Karapandža. Demudding and canal cleaning as activities in nature protection are of special importance for preservation of wetland habitats.

Photo by V. Stojanović

the managerial body, 2013). All the activities are in accord with the obligations of the management pursuant to the Law on nature protection (Official Gazette of the Republic of Serbia, No. 36/2009).

Since the proclamation of Special nature reserve "Gornje Podunavlje" several activities have been conducted with the aim of preserving and protection of natural assets. These activities have been mainly focused on preservation of natural features of wetlands, which have been drained for centuries.

During the preparation activities for proclamation of special nature reserve in its south part, known as Apatinski rit, several interventions were conducted with the aim to provide undisturbed flow of the flooding Danube. At the locality Staklara, due to the building of the local road for forestry needs, the canal Bakšan was obstructed. Pipe installation into the road draiange ditches re-enabled unobstructed flow of water, essential for habitats in north Staklara. At the same time the Staklarski bifurcation was covered with soil and baffled. The demudding works preserved this valuable meandre with the regime of the second level protection.

In the north part of the reserve several hydrological regulation works to preserve wetlands were con- ducted. At the locality Karapandža the works on canal Sirota (to irrigate and maintain wet areas (Figure 2)) were conducted in 2012. In the future, the water will be let into the water intake structure to the desired water level. Apart from hydrotechnical adaptation of forest and swamp area in Karapandža, project implementation would enable water utilisation for irigation of cultivated land outside the area. The works on demudding the water canal Sirota were also the part of the project (www.vdpzapadnabacka.co.rs/aktuelno.htm).

Cooperation of management with Provincial institute for nature protection and Provincial secretariat for urbanism, civil engineering and nature protection brought to revitalisation of wetlands at locality Strbac, in the north part of the reserve. This area is especially important for mosaic type of habitat which has been degraded due to negative anthropogenic influence. The locality is recognisable not only by its prevailing xerophylous forests adapted to salty land, salty marshes, wet depressions, but also by the meandering river Plazović and several swamps.Semenjača swamp is completely covered in shrubs 2-3 meters high. Parts of these plants were picked by hydraulic cable to avoid the possibility of regrowth. Biomass was deposited out 
of the reserve in abandoned clay pits. Open water areas that are suitable as habitats for numerous species were recreated by removing hydrofile vegetation. Such actions of ecological management definitely have great impact on preservation of wetlands, which further influence micro- and mesoclimate to a certain extent. The wetlands impact on air temperature and precipitation is obvious, thus they moderate climatic changes.

Research area is located in the southern part of the Pannonian Plain, characterized by Holocene sediments with gentle relief, and the climate is generally free from orographic effects. According to KöpenGeiger climate classification, the region is categorized as Cf climate (temperate warm climate with a rather uniform annual distribution of precipitation) (Kottek et al. 2006). Therefore, wetlands probably have an influence on microclimate conditions, i.e. decrease extreme cold spells during the winter and high temperatures during the summer. At the same time, it can be noticed a slightly increasing tendencies in precipitation amount, comparing to agricultural bare lands in surroundings.

Biological research and monitoring organized by several institutions, including the managerial one are of highest importance, such as monitoring of Whitetailed Eagle (Haliaeetus albicilla), Black Stork (Ciconia nigra) and protection and improvement of nesting conditions for Tawny Owl (Strix aluco). Apart from organized monitoring and research of certain species, there has been a continuous work on project research, revitalization and protection of habitat projects in Crna bara and Široki rit. These projects are realized in cooperation with World Wildlife Fund and mainly aimed at protection of wetland habitats in "Gornje Podunavlje". Otherwise, protection of similar areas has been improved in recent years and WWF has set the goal to protect 1.5 million hectares of flooded areas or to connect them with the river by the year 2020 .

Frequently, protection and management programmes highlight the importance of education in ecology, especially in terms of tourism development. Ecotourism is based on visits by tourist, experts and individuals interested in nature protection and learning about nature.Ecotourism may significantly contribute to raising awareness about nature conservation (Fennel, 1999). Educative and thematic tours/ trails that provide information on natural values are segments of tourist offer. There are three marked trails in Special nature reserve "Gornje Podunavlje": Karapandža $(3 \mathrm{~km})$; Bestrement $(3 \mathrm{~km})$ and Štrbac (2 $\mathrm{km})$. The management of the Special nature reserve "Gornje Podunavlje" also offers the following activities for tourists: renting a boat, sailing on the Danube for organized groups, tourist guide services, photograph- ing the endangered species, driving a terrain vehicle and taking a carriage ride. Increasing ecotourism trends are expected in the reserve in the future years.

However, the development of forestry is the most disputed issue in management type applied in the "Gornje Podunavlje". The main problem is the over breeding the poplar trees. Protected areas in Serbia are also managed by the institutions appointed by the state to manage the forests. Occasionally, there is the public opinion that interventions and jurisdiction of management as economic user of forests and nature protectors are uncoordinated (Puzović, 2002).

\section{Biosphere reserve status - sustainable development model in "Gornje Podunavlje" and the region}

Serbia nominated a part of its territory for transboundary biosphere reserve Mura - Drava - Danube in September 2013 (Panjković et al, 2013). Proposal for biosphere reserve, which will be shared nd managed by five countries (Austria, Slovenia, Hungary, Croatia and Serbia) was submitted by WWF and EuroNatura (Figure 3). These organsiations have led the campaign for protection of the rivers Mura, Drave, Danube and against all forms of their pollution and degradation from the early 1990s. During such activities the governments of countries proclaimed 13 protected areas, enabling of transboundary cooperation. Only Croatian and Hungarian parts of biosphere reserve have been officially approved. Awaiting the proclamation of the Danube banks in Bačka, where Special nature reserve "Gornje Podunavlje" lies, as the part of transboundary biosphere reserve, a question arises about opportunities that this status brings in nature protection and exploitation of resources.

Biosphere reserves are inland and coastal ecosystems recognised within UNESCO programme: Man and biosphere. Every biosphere reserve should fulfil three criteria: protection - comprising the preservation of genetic resources, types, ecosystems and landscapes; development - which enables economic and social development and support - which comprises demonstrational projects, training and education in environment protection.

Challenges in protecting natural assets should also be observed through the aspirations to the proclamation of biosphere reserve. For centuries "Gornje Podunavlje" has been under fierce impact of economic activities of the people. With the tendency to protect this area at international level it is urgently needed to apply concept of sustainable development to protection and exploitation of the resources in "Gornje Podunavlje". Sensibility of wetland ecosystems and flooded plains additionally complicates this task. The solu- 


\section{Transboundary river system of the Mura, Drava and Danube}

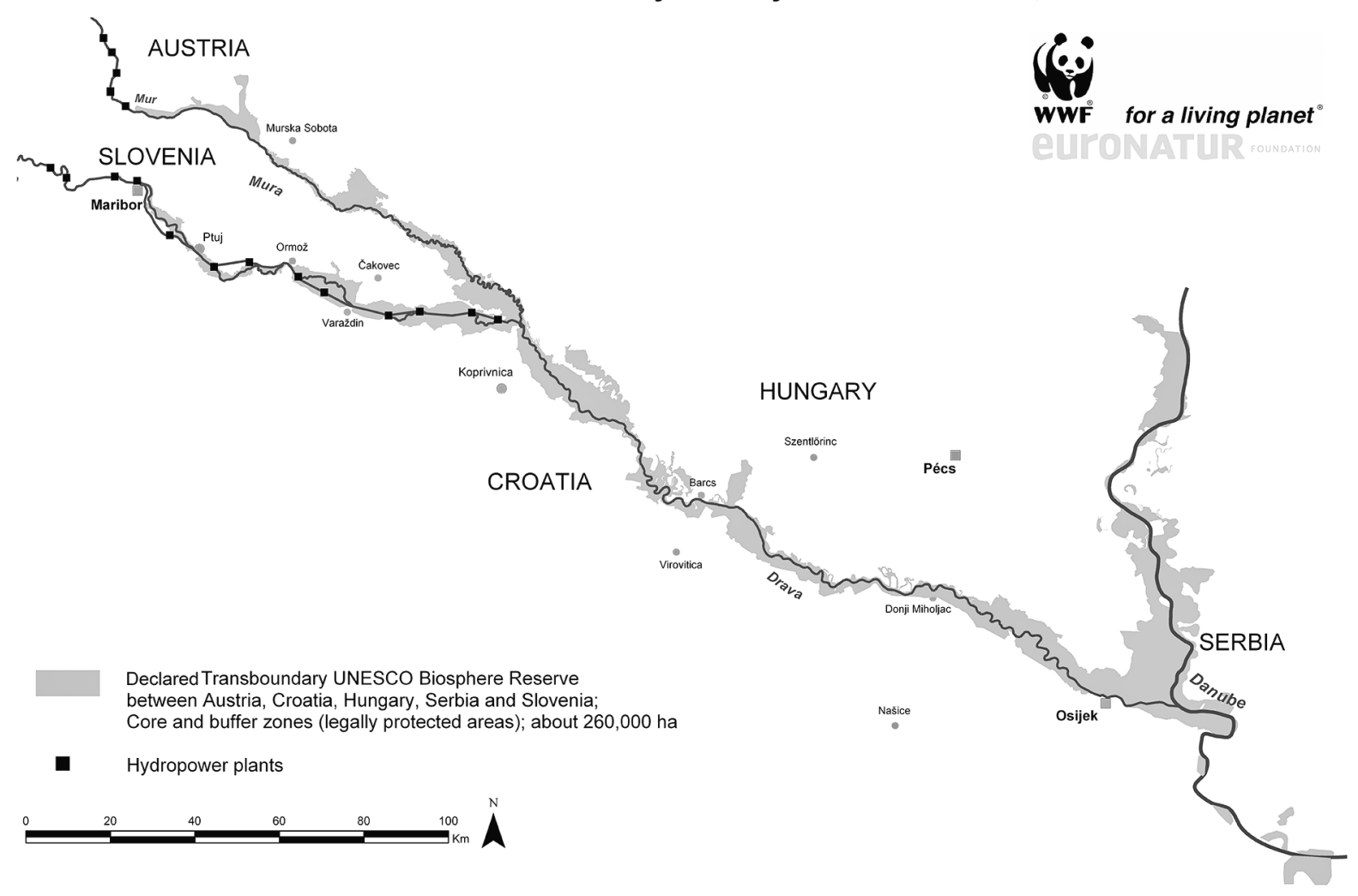

Figure 3. Riverbanks of the Mura, the Drava and the Danube - potential cross boundaries biosphere reserve, known as European Amazon

tions of sustainable development are to be sought in cooperation and experience exchange with countries sharing the biosphere reserve, since all its parts share similar history of utilisation of the area, which was based on the development of agriculture, fishing, cattle breeding and forestry (Trenc et al, 2007; Hungarian-Croatian Mura-Drava-Danube Transboundary Biosphere Reserve, 2009; Panjković et al, 2013). Basic activity should be directed to preserving valuable ecosystems, then to sustainable development of economic activities such as ecological agriculture and ecotourism. Most of the biosphere reserves perceive their opportunity in tourism and similar situation is valid for all neighbouring countries (Johnson, 2004). Furthermore, forestry needs to rest upon the principles of sustainable development and integrate into principles of nature protection.

Habitat revitalisation activities are needed in order to diminish negative impacts from the past, which is not only the feature of "Gornje Podunavlje", but also of the areas in neighbouring Hungary and Croatia. There is also the opportunity for employment of the local population by participating in the projects.

\section{Conclusion}

The landscapes in "Gornje Podunavlje" were strongly influenced by agriculture, melioration and forestry in the past. However, the patches of well-preserved nature rightfully deserve national protection category as well as numerous international protections statuses (IBA, IPA, Ramsar, MaB). Ruined and devastated localities, primarily habitats subject to changes due to the lack of water where it was the dominant factor of the environment, have to be revitalised (e.g. Monoštorski rit, Karapandža, Štrbac). Biosphere reserve status should enable larger investments in similar projects thus confirming the global importance of the protected area. With regard to the fact that nature degradation process is caused by human activities, it is highly important that biosphere reserve status demonstrates different types of sustainable development. As far as "Gornje Podunavlje" is concerned, those new types can and have to be found in new research, ecological education, tours in the reserve, programmes of tourism development and benefits for the locals who reasonably expect a lot from this project. 


\section{Acknowledgment}

The authors acknowledge the financial support of the Ministry of Education and Science of the Republic of Serbia (Project III 43005)

\section{References}

Baker, S. 2006. Sustainable Development. Routledge. Abingdon.

Borovszky, S. 1909. Bács-Bodrog vármegye, Budapest. Bukurov, B. 1975. Physical-geografical problems in Bačka, Serbian Academy of Sciences and Arts, Department of natural sciences, book 43, Belgrade

Bukvić, M. 1969. Apatin through centuries, Culturaleducational community, Apatin.

Elliott, J. 2013. An Introduction to Sustainable Development. Routledge. Abingdon.

Greemet, R., Jones, C. 1989. Important Bird Areas in Europe - Yugoslavia. ICBP TehnicalPublication.

Hydrological study of Monoštorski rit Siga-Kazuk, Faculty of agriculture, Scientific-educational institute for water management, Novi Sad, 1988.

Hungarian-Croatian Mura-Drava-Danube Transboundary Biosphere Reserve, Budapest, 2009.

Internal data and documents of the managerial body, 2013.

Johnson, C., (2004): Ecotourism Planning Considerations in eastern Central Europe, Ecotourism: Management and Assessment, Thomson, London.

Fennel, D., A., 1999. Ecotourism: An introduction, Routledge, London.

Kottek, M., Grieser, J., Beck, C., Rudolf, B., Rubel, F. 2006. World map of the Köppen-Geiger climate classification updated. Meteorologische Zeitschrift 15, 259-263.

Kovačević, B., et al, 200o. Special nature reserve "Gornje Podunavlje", Proposal for protecting the area as natural asset of extraordinary importance, Institute for nature protection in Serbia, Department in Novi Sad, Novi Sad.

Medović, P. 2001. Prehistory on the territory of Vojvodina. Prometej. Military publishing institute. Novi Sad.
Milošev, Ž. 2002. Hydro-technical workd in Banat and Bačka prior to building the hydrosystem Danube-Tisa-Danube, Hydrosystem Danube-TisaDanube - 25 years later, Public company Vode Vojvodine, NoviSad, 1-22.

Panjković B., Tucakov, M., Perić, R., Delić, J., Pil, N., Galamboš. L., Dobretić, V., Sabadoš, K., Kovačev, N., Bošnjak, T., Timotić, D., Kiš, A., Stojanović, V., Sekulić, G., Erg, B., Dimović, D., Bađura, S., 2013. Mura - Drava - Danube, Biosphere Reserve Nomination Form, Novi Sad (Serbia).

Petrović, N. 1978. Navigation and economy of the Middle Danube during mercantilist period, Historical institute, Belgrade.

Puzović, S. 2002. Poplar plantages and protection of wetlands and biodiversity, Forests, No. 67, Serbian forests, Belgrade.

Stojanović, V. 2005. Sustainable tourism in special nature reserves in Vojvodina, Department of Geography, Tourism and Hotel Management, Faculty of Science, Novi Sad.

Stojanović, V., Đorđević, J., Lazić, L., Stamenković, I., Dragićević, V. 2013. The Principles of Sustaineble Development of Tourism in the Special Nature Reserve "Gornje Podunavlje" and their impact on the local Communities. Acta Geographica Slovenica. Special issue - SyCULTour 2014. http://giam.zrcsazu.si/?q=en/node/640

Trenc, N., Barić, B., Palada, D., Rodić-Baranović, P., Duplić, A., Jeremić, J., Kopjar, S., Grlica, I., Vukelić, J., Trninić, D., Karoglan-Todorović, S., Mračković, M., Marčić, Z., Mađerić, B., Mikuska, T., 2007. Mura - Drava - Danube, Biosphere Reserve Nomination Form, State Institute for Nature Protection (Croatia).

Decree on protection in Special nature reserve "Gornje Podunavlje", Official Gazette of the Republic of Serbia, No. 45, 2001.

Law on nature protection, Official Gazette of the Republic of Serbia, No. 36/2009.

www.gornjepodunavlje.info

www.ramsar.org

www.unesco.org

www.vdpzapadnabacka.co.rs/aktuelno.htm 